ISSN: 2302-8556

E-Jurnal Akuntansi Universitas Udayana

Vol.24.1.Juli (2018): 687-714

DOI: https://doi.org/10.24843/EJA.2018.v24.i01.p26

\title{
Analisis Perbandingan Kinerja Keuangan Perusahaan Sebelum dan Sesudah Merger dan Akuisisi Periode 2011-2014
}

\author{
I Putu Doni Aditya Septiawan ${ }^{1}$ \\ Ni Ketut Rasmini ${ }^{2}$
}

${ }^{1}$ Fakultas Ekonomi dan Bisnis Universitas Udayana (Unud), Bali, Indonesia
email:doniaditya1909@ gmail.com/Tlp: +6281916602193
${ }^{2}$ Fakultas Ekonomi dan Bisnis Universitas Udayana (Unud), Bali, Indonesia

\begin{abstract}
ABSTRAK
Pencapaian sinergi merupakan tujuan dari perusahaan melakukan merger dan akuisisi sekaligus memperbaiki kinerja keuangan perusahaan. Penelitian ini bertujuan untuk mengetahui apakah terdapat peningkatan kinerja keuangan pada perusahaan yang mengalami financial distress dan yang tidak mengalami financial distress selama lima tahun sebelum dan dua tahun sesudah merger dan akuisisi. Perusahaan yang dijadikan sampel dipilih menggunakan metode purposive sampling sehingga diperoleh sampel sebanyak 33 perusahaan. Kinerja keuangan perusahaan diukur dengan lima rasio yakni Current Ratio (CR), Return on Asset (ROA), Return on Equity (ROE), Debt to Equity (DER) dan Total Asset Turnover (TATO). Teknik analisis yang digunakan dalam penelitian ini adalah altman z-score, uji statistik deskriptif, uji normalitas dan paired sample t test. Hasil pengujian menunjukkan bahwa kinerja keuangan pada perusahaan yang mengalami financial distress dan perusahaan yang tidak mengalami financial distress tidak mengalami peningkatan pasca merger dan akuisisi.
\end{abstract}

Kata kunci : kinerja keuangan, financial distress, merger dan akuisisi

\begin{abstract}
Achieving synergies is the goal of companies performing mergers and acquisitions while improving the company's financial performance. This study aims to determine whether there is an increase in financial performance in companies experienced financial distress and who did not experience financial distress for five years before and two years after mergers and acquisitions. The companies were selected using purposive sampling method to obtain 33 samples. The company's financial performance is measured by five ratios: Current Ratio (CR), Return on Asset (ROA), Return on Equity (ROE), Debt to Equity (DER) and Total Asset Turnover (TATO). Analytical techniques used in this study are altman z-score, descriptive statistical test, normality test and paired sample t test. The test results show that the financial performance of companies experiencing financial distress and companies that do not experience financial distress did not experience an increase after mergers and acquisitions

Keywords: financial performance, financial distress, mergers and acquisitions
\end{abstract}

\section{PENDAHULUAN}

Perkembangan teknologi informasi mengakibatkan persaingan antar perusahaan meningkat. Perusahaan akan menghindari lingkungan persaingan yang tidak sehat dan cenderung saling mengalahkan. Lingkungan semacam ini tanpa disadari akan merugikan perusahaan-perusahaan yang berada pada lingkungan tersebut. 
I Putu Doni Aditya S. dan Ni Ketut Rasmini. Analisis...

Perusahaan akan memilih strategi kerjasama dalam bentuk penggabungan (merger) dan pengambilalihan usaha (akuisisi) baik dengan perusahaan yang masih dalam satu lingkup usaha maupun perusahaan dengan lingkup usaha berbeda sebagai strategi alternatif yang lebih menguntungkan perusahaan.

Pasal 1 Ayat 9 Undang-undang Perseroan Terbatas Nomor 40 (UUPT) tahun 2007 didefinisikan bahwa merger merupakan perbuatan hukum yang dilakukan oleh satu perseroan atau lebih untuk menggabungkan diri dengan perseroan lain yang telah ada yang mengakibatkan aktiva dan pasiva dari perseroan yang menggabungkan diri beralih karena hukum kepada perseroan yang menerima penggabungan dan selanjutnya status badan hukum perseroan yang menggabungkan diri berakhir karena hukum. Pada pasal 11 ayat 11 UUPT Nomor 40 tahun 2007 menjelaskan bahwa akuisisi merupakan perbuatan hukum yang dilakukan oleh badan hukum atau orang perseorangan untuk mengambil alih saham perseroan yang mengakibatkan beralihnya pengendalian atas perseroan tersebut.

Fahlevi (2013) mengemukakan bahwa umumnya manajemen memilih merger dan akuisisi dengan tujuan untuk mengurangi pajak yang dibebankan kepada perusahaan, membeli aset dengan harga yang relatif lebih rendah, diversifikasi bisnis dan juga sinergi. Pada penelitiannya, Riza juga mengemukakan bahwa alasan yang paling dominan adalah sinergi. Sinergi merupakan nilai keseluruhan perusahaan setelah merger dan akuisisi yang lebih besar daripada penjumlahan nilai masing-masing perusahaan sebelum merger dan akuisisi. Sinergi yang baik akan tercermin dari kinerja perusahaan setelah 
dilakukannya merger dan akuisisi (Edfan Darlis dan Zirman, 2009). Namun, kinerja perusahaan tidak selalu mengalami peningkatan meskipun telah dilakukannya merger dan akuisisi.

Penilaian yang tepat dan akurat pada perusahaan target kemudian merancang peramalan yang baik serta strategi jangka panjang yang tepat merupakan hal yang penting untuk dilakukan sebelum memutuskan untuk melakukan merger dan akuisisi sehingga sinergi antar kedua perusahaan akan lebih mudah dicapai. Hal tersebut seringkali tidak dilakukan dengan baik oleh perusahaan sehingga tidak jarang merger dan akuisisi justru tidak mampu mengangkat kinerja perusahaan. Keadaan keuangan perusahaan juga perlu diperhatikan untuk menentukan strategi pendekatan yang tepat pada perusahaan tersebut.

Perusahaan yang memiliki keadaan keuangan yang baik, akan memilih strategi merger dan akuisisi sebagai upaya untuk meningkatkan kekuatan perusahaan. Berbeda dengan perusahaan yang berada dalam keadaan keuangan sulit (financial distress) akan memilih strategi merger dan akuisisi sebagai upaya untuk memperbaiki kinerja keuangannya. Secara definisi financial distress merupakan suatu keadaan dimana kondisi keuangan perusahaan dalam keadaan tidak sehat atau sedang kritis (Platt dan Platt, 2002).

Strategi merger dan akuisisi ini kerap dipilih perusahaan yang mengalami financial distress sebagai langkah yang tepat untuk memperbaiki kinerja keuangan perusahaan seperti yang dilakukan PT. XL Axiata Tbk. (XL) terhadap PT. Axis Telekom Indonesia (AXIS) pada tahun 2014. PT. XL Axiata Tbk. 
(XL)melakukan aksi merger dan akuisisi terhadap PT. Axis Telekom Indonesia (AXIS) dengan menggunakan dana pinjaman sebesar US\$865 juta pada tahun 2014.

Keputusan menggunakan dana pinjaman ini diambil karena pada saat itu XL sedang berada dalam kondisi financial distress. Namun, AXIS dinilai memiliki potensi yang dapat dimanfaatkan XL dimasa mendatang sehingga keputusan merger dan akuisisi terhadap Axis ini tetap dilaksanakan oleh manajemen XL. Selain untuk memperbaiki kinerja keuangan secara internal, manajemen juga melakukan langkah ini untuk memperluas pangsa pasar yang dimiliki perusahaan sehingga diharapkan sebaran produk yang lebih luas dapat memberikan peningkatan pendapatan perusahaan.

Penelitian ini bertujuan untuk mengetahui apakah terdapat peningkatan kinerja keuangan pada perusahaan yang mengalami financial distress dan yang tidak mengalami financial distress selama lima tahun sebelum dan dua tahun sesudah merger dan akuisisi. Perusahaan perlu memperhatikan keadaan keuangan perusahaan apakah berada pada zona financial distress atau tidak serta mempertimbangkan tren kinerja keuangan perusahaan sehingga pencapaian sinergi yang diharapkan pasca merger dan akuisisi menjadi lebih mudah untuk dilakukan.

Teori sinyal menjelaskan suatu tanda yang diberikan oleh manajemen kepada pihak-pihak yang memiliki kepentingan terhadap perusahaan tentang bagaimana manajemen melihat prospek perusahaan di masa depan (Wolk et al., 2001). Laporan keuangan perusahaan memberikan sinyal atau tanda kepada 
pengguna laporan keuangan mengenai bagaimana kondisi keuangan perusahaan pada periode tersebut, apakah perusahaan berada dalam keadaan sehat ataupun dalam keadaan kesulitan keuangan (financial distress) (Mas'ud, Imam dan Reva Maymi Srengga, 2012)

Beberapa penelitian yang telah dilakukan untuk memberikan gambaran tentang bagaimana kinerja perusahaan setelah merger dilakukan. Diantaranya yakni dilakukan oleh Priya dkk., (2017) yang meneliti tentang kinerja keuangan perusahaan pada 30 perusahaan sebelum dan sesudah merger dan akuisisi. Penelitiannya menyimpulkan bahwa kinerja perusahaan mengalami peningkatan khususnya pada current ratio(CR), total asset turnover(TATO), fixed asset turnover(FATO), debt to equity ratio (DER), net profit margin(NPM), return on asset(ROA), dan earnings per share(EPS).

Neelam Rani dkk (2013) meneliti tentang dampak merger dan akuisisi terhadap kinerja keuangan perusahaan menyimpulkan bahwa secara keseluruhan perusahaan yang melakukan merger dan akuisisi di India mengalami peningkatan kinerja perusahaan setelah merger dan akuisisi dilakukan. Peng dan Vijay (2012) juga menemukan terjadinya perbaikan kinerja keuangan perusahaan dalam jangka pendek pasca merger dan akuisisi. Keberhasilan merger dan akuisisi dapat dilihat dari adanya peningkatan kinerja keuangan pada perusahaan. Setelah perusahaan melakukan merger ukuran perusahaan akan bertambah besar oleh karena adanya pertambahan aset, kewajiban dan ekuitas perusahaan.

$\mathrm{H}_{1} \quad$ : Terdapat peningkatan kinerja keuangan perusahaan sesudah merger dan akuisisi. 
Merger dan akuisisi pada perusahaan yang mengalami financial distress menjadi daya tarik tersendiri bagi perusahaan bidder. Saham perusahaan tersebut seringkali diperdagangkan pada harga rendah yang menggambarkan kesulitan yang dihadapi perusahaan. Perusahaan yang mengalami financial distress akan terdorong untuk menjual cepat saham dan aset mereka untuk meningkatkan modalnya atau untuk membayar hutangnya (Wacthell et al., 2017).

Perusahaan yang mengalami financial distress dapat bangkit kembali melalui aktivitas merger dan akuisisi (Heyer dan Sheldon, 2009). Hal ini dapat terjadi karena perusahaan pengakuisisi ataupun yang diakuisisi memiliki pekerja ahli yang lebih baik dalam menjalankan perusahaan sejenis, manajemen perusahaan yang memiliki pengetahuan lebih baik tentang cara menghadapi perkembangan pasar, dan mampu mencapai sinergi melalui penggabungan kemampuan perusahaan dengan aset perusahaan yang mengalami keadaan financial distress (Quxian Zhang, 2016).

Maeseneire (2011) menemukan bahwa perusahaan yang mengalami financial distress memiliki keuntungan investasi yang lebih baik karena proses restrukturisasi lebih mudah dilakukan pada perusahaan ini sehingga kegagalan manajemen sebelumnya dalam menjaga efisiensi dapat perbaiki melalui merger dan akusisi.Hal senada juga dikemukakan oleh Jean Marie (2014) bahwa kinerja perusahaan yang mengalami financial distress mengalami peningkatan setelah merger dan akuisisi.

Stuart Gilson (2015) menyebutkan bahwa dari 75 pengakuisisian perusahaan pada perusahaan dengan financial distress, sebanyak 66 perusahaan 
(89 persen) mengalami peningkatan kinerja pada waktu satu hingga dua tahun pasca akuisisi. Wolvers (2017) yang meneliti kinerja keuangan pada 107 perusahaan yang mengakuisisi perusahaan yang mengalami financial distress dengan rasio return on asset (ROA) dan capital to asset ratio (CAR) sebagai alat ukurnya juga menemukan bahwa akuisisi berpengaruh positif pada ROA dan CAR pada perusahaan yang mengalami financial distress yang diakuisisi.

$\mathrm{H}_{2}$ : Terdapat peningkatan kinerja keuangan pada perusahaan yang mengalami financial distress sesudah merger dan akuisisi.

$\mathrm{H}_{3}$ : Terdapat peningkatan kinerja keuangan pada perusahaan yang tidak mengalami financial distress sesudah merger dan akuisisi.

\section{METODE PENELITIAN}

Populasi yang digunakan pada penelitian ini adalah perusahaan-perusahaan yang melaporkan aksi korperasi merger dan akuisisinya pada Komisi Pengawas Persaingan Usaha pada periode 2011-2014. Objek dari penelitian ini adalah kinerja keuangan perusahaan yang dapat diukur menggunakan rasio likuiditas, rasio profitabilitas, rasio solvabilitas dan rasio aktivitas. Metode penentuan sampel yang digunakan pada penelitian ini adalah teknik nonprobability sampling dengan metode purposive sampling dengan kriteria sebagai berikut: 1) Perusahaan yang melakukan merger dan akuisisi terdaftar di Bursa Efek Indonesia periode 2011-2014. Hal ini diperlukan untuk memperoleh data mengenai harga pasar saham perusahaan sebelum dan sesudah merger dan akuisisi. 2)Perusahaan menerbitkan laporan keuangan yang berakhir pada tanggal 31 Desember selama periode pengamatan yakni 5 tahun sebelum dan 2 tahun setelah merger dan akuisisi. Laporan keuangan selama lima tahun sebelum merger dan akuisisi 
I Putu Doni Aditya S. dan Ni Ketut Rasmini. Analisis...

diperlukan untuk melihat tren keadaan keuangan perusahaan, dan laporan keuangan selama dua tahun sesudah merger dan akuisisi diperlukan untuk melihat kemampuan perusahaan dalam mencapai sinergi jangka pendek pasca merger dan akuisisi. 3)Perusahaan memiliki data keuangan yang lengkap untuk menghitung variabel-variabel pada penelitian ini.

Data keuangan yang lengkap diperlukan untuk menghitung rasio-rasio keuangan yang digunakan dalam penelitian ini. Selain itu, kelengkapan data keuangan tersebut juga dibutuhkan untuk mengklasifikasikan keadaan keuangan perusahaan menggunakan model kebangkrutan Altman Z-Score. Secara rinci pemilihan sampel penelitian akan disajikan pada tabel 1 sebagai berikut.

Tabel 1.

Pemilihan Sampel Penelitian

\begin{tabular}{llc}
\hline No & Keterangan & Jumlah \\
\hline 1 & $\begin{array}{l}\text { Perusahaan yang melaporkan aksi korporasi merger dan akuisisi pada KPPU } \\
\text { periode 2011-2014 }\end{array}$ & 168 \\
2 & $\begin{array}{l}\text { Perusahaan merger dan akuisisi yang tidak terdaftar di BEI 2011-2014 } \\
3\end{array}$ & $\begin{array}{l}\text { Perusahaan yang tidak memiliki laporan keuangan lima tahun sebelum dan } \\
\text { dua tahun setelah merger dan akuisisi }\end{array}$ \\
& Perusahaan yang tidak memiliki data keuangan yang lengkap & $(15)$ \\
\hline & Total sampel perusahaan merger dan akuisisi & $(3)$ \\
\hline
\end{tabular}
Sumber: Data diolah, 2018

Berdasarkan Tabel 1, maka diperoleh jumlah perusahaan yang memenuhi kriteria penentuan sampel untuk penelitian ini sebanyak 33 perusahaan. Definisi operasional variabel-variabel yang digunakan dalam penelitian ini adalah sebagai berikut:

1) Financial distress ini diukur dengan menggunakan Bankrupt Prediction Model milik Altman yang disebut dengan Altman Z-Score.

Rumus yang digunakan dengan metode Altman Z-Score adalah

$$
\mathrm{Z}=1,2 \mathrm{X}_{1}+1,4 \mathrm{X}_{2}+3,3 \mathrm{X}_{3}+0,6 \mathrm{X}_{4}+1,0 \mathrm{X}_{5}(\text { Altman, 1968). }
$$




\section{Keterangan :}

$\mathrm{X}_{1}$ : Modal kerja terhadap total aset.

$\mathrm{X}_{2}$ : Laba yang ditahan terhadap total aset.

$\mathrm{X}_{3}$ : Pendapatan sebelum pajak dan bunga terhadap total aset.

$\mathrm{X}_{4}$ : Nilai pasar ekuitas terhadap nilai buku hutang.

$\mathrm{X}_{5}$ : Penjualan terhadap total aset.

Kriteria yang digunakan untuk memprediksi kebangkrutan perusahaan dengan model ini adalah, perusahaan yang mempunyai skor $Z>2,90$ diklasifikasikan sebagai perusahaan sehat, sedangkan perusahaan yang memiliki skor $\mathrm{Z}<1,80$ diklasifikasikan sebagai perusahaan yang berpotensi bangkrut. Selanjutnya skor antara 1,80 sampai 2,90 diklasifikasikan sebagai perusahaan pada area abu-abu atau perusahaan yang rawan bangkrut (Altman, 1968).

2) Kinerja keuangan ini diukur menggunakan rasio likuiditas, rasio aktivitas, rasio solvabilitas, dan rasio profitabilitas.

(a) Rasio Likuiditas (Anisa Aristanti, 2017):

$$
\text { Current Ratio }=\frac{\text { Aset Lancar }}{\text { Hutang Lancar }}
$$

(b) Rasio Profitabilitas (Anisa Aristanti, 2017):

$$
\begin{aligned}
& \text { Return on Asset }=\frac{\text { Laba setelah pajak }}{\text { Aset }} \ldots \\
& \text { Return on Equity }=\frac{\text { Laba setelah pajak }}{\text { Ekuitas }} .
\end{aligned}
$$

(c) Rasio Solvabilitas(Anisa Aristanti, 2017):

Debt to Equity Ratio= $\frac{\text { Total Hutang }}{\text { Ekuitas }}$

(d) Rasio Aktivitas (Anisa Aristanti, 2017):

Total Asset Turnover $=\frac{\text { Penjualan }}{\text { Total Aset }}$ 
Metode pengumpulan data yang digunakan dalam penelitian ini adalah metode observasi nonpartisipan, yaitu teknik pengumpulan data dengan observasi dimana peneliti tidak terlibat langsung dan hanya sebagai pengamat independen (Sugiyono, 2017).Data yang digunakan dalam penelitian ini adalah data kuantitatif berupa data mengenai Current Ratio, Return on Asset, Return on Equity, Debt to Equity Ratio, dan Total Asset Turn Over serta data mengenai variabel-variabel yang dibutuhkan untuk menghitung Altman Z-Score yang diperoleh dari Indonesian Capital Market Directory (ICMD) 2007, 2008, 2009, 2010, 2011, 2012, 2013, dan 2014, serta Annual Report perusahaan sample pada tahun 2014, 2015 dan 2016.

Teknik analisis data yang digunakan pada penelitian ini adalah uji normalitas, Altman Z-Scoredan juga uji paired sample t test atau wilcoxon sign rank test. Uji normalitas data akan menggunakan Uji Kolmogorov Smirnovdengan tingkat signifikansi sebesar $\alpha=0,05$. Altman Z-Score digunakan untuk mengklasifikasikan perusahaan berdasarkan kondisi keuangaannya selama lima tahun sebelum merger dan akuisisi. Selanjutnya, untuk menguji hipotesis makan akan menggunakanmodel analisis paired sample $t$ test apabila variabel yang diujikan berdistribusi normal dan model analisis wilcoxon sign rank test apabila variabel yang diujikan tidak berdistribusi normal. Uji normalitas data akan menggunakan uji kolmogorov smirnov.

\section{HASIL DAN PEMBAHASAN}

Uji Altman Z-Score dilakukan untuk mengklasifikasikan keadaan keuangan perusahaan sebelum dan sesudah merger dan akuisisi. Apabila nilai Z-score lebih 
besar dari $\mathrm{Z}>2,90$ maka akan diklasifikasikan sebagai perusahaan sehat (healthy), pada perusahaan yang memiliki skor $\mathrm{Z}<1,80$ diklasifikasikan sebagai perusahaan yang berpotensi bangkrut (financial distress) dan pada perusahaan dengan skor antara 1,80 sampai 2,90 akan diklasifikasikan sebagai perusahaan pada area abu-abu atau perusahaan yang rawan bangkrut. Daftar perusahaan yang mengalami financial distress dan yang tidak mengalami financial distress berdasarkan rata-rata nilai Z-Score selama lima tahun sebelum merger dan akuisisi, secara berurutan akan disajikan pada Tabel 2 dan Tabel 3.

Berdasarkan Tabel 2 dan Tabel 3 diatas terdapat sebanyak10 perusahaan yang mengalami financial distress dan sebanyak 23 perusahaan yang tidak mengalami financial distress sebelum merger dan akusisi. Penilaian Z-Score ini sangat dipengaruhi oleh data laporan keuangan perusahaan khususnya data mengenai aset, penjualan, laba, hutang, harga saham, dan jumlah saham yang beredar.

Tabel 2.

Daftar Perusahaan yang Mengalami Financial Distress Sebelum Merger dan Akuisisi

\begin{tabular}{ccccc}
\hline No & Kode Perusahaan & Tahun M\&A & Z-Score & Keterangan \\
\hline 1 & JSMR & 2011 & 1,62 & Distress \\
2 & KIJA & 2011 & 0,92 & Distress \\
3 & LPPF & 2011 & 1,21 & Distress \\
4 & ICON & 2011 & 0,55 & Distress \\
5 & ASRI & 2012 & 1,77 & Distress \\
6 & MLPL & 2012 & 1,39 & Distress \\
7 & TKIM & 2013 & 1,04 & Distress \\
8 & SUGI & 2013 & 1,71 & Distress \\
9 & APLN & 2014 & 1,62 & Distress \\
10 & BCAP & 2014 & 1,29 & Distress \\
\hline Sumber: Data diolah, 2018 & & &
\end{tabular}


Tabel 3.

Daftar Perusahaan yang Tidak Mengalami Financial Distress Sebelum Merger dan Akuisisi

\begin{tabular}{ccccc}
\hline No & Kode Perusahaan & Tahun M\&A & Z-Score & Keterangan \\
\hline 1 & UNVR & 2011 & 15,48 & Healthy \\
2 & ANTM & 2011 & 8,35 & Healthy \\
3 & CPIN & 2011 & 5,29 & Healthy \\
4 & MAPI & 2011 & 2,70 & Grey Area \\
5 & TPIA & 2011 & 2,71 & Grey Area \\
6 & INDY & 2012 & 2,27 & Grey Area \\
7 & JPFA & 2012 & 3,20 & Healthy \\
8 & KLBF & 2012 & 8,90 & Healthy \\
9 & SCMA & 2012 & 6,97 & Healthy \\
10 & SMCB & 2012 & 3,30 & Healthy \\
11 & TURI & 2012 & 4,85 & Healthy \\
12 & UNTR & 2012 & 4,83 & Healthy \\
13 & AUTO & 2013 & 5,26 & Healthy \\
14 & HRUM & 2013 & 12,77 & Healthy \\
15 & BYAN & 2013 & 4,42 & Healthy \\
16 & TELE & 2013 & 10,34 & Healthy \\
17 & KPIG & 2013 & 6,63 & Healthy \\
18 & TINS & 2013 & 6,45 & Grey Area \\
19 & INDS & 2013 & 2,82 & Grey Area \\
20 & MDLN & 2014 & 2,13 & Grey Area \\
21 & EXCL & 2014 & 2,19 & Grey Area \\
22 & ASII & 2014 & 4,10 & Healthy \\
23 & AALI & 2014 & 11,46 & Healthy \\
\hline
\end{tabular}

Sumber: Data diolah, 2018

Uji ini alat analisis yang digunakan adalah Kolmogorov-Smirnov Test dengan taraf signifikansi yang digunakan adalah 5 persen atau 0,05. Data akan dinyatakan berdistribusi normal apabila tingkat signifikansinya lebih besar dari 0,05 dan apabila tingkat signifikansinya lebih rendah maka data akan dinyatakan tidak berdistribusi normal. Hasil dari uji normalitas pada kinerja keuangan perusahaan pada seluruh sampel penelitian, pada persuahaan yang mengalami financial distress dan pada perusahaan yang tidak mengalami financial distress sebelum dan sesudah merger dan akuisisi akan disajikan secara berturut-turut pada Tabel 4, Tabel 5, dan 6 sebagai berikut: 
Tabel 4.

Hasil Uji Normalitas Pada Kinerja Keuangan Perusahaan Sebelum dan Sesudah Merger dan Akuisisi

\begin{tabular}{cccccc}
\hline \multicolumn{2}{c}{ Variabel } & N & Sig. (2.tailed) & Taraf Sig. & Kesimpulan \\
\hline CR & Sebelum & 33 & 0,26102 & 0,05 & Normal \\
ROA & Sebelum & 33 & 0,88176 & 0,05 & Normal \\
ROE & Sebelum & 33 & 0,16100 & 0,05 & Normal \\
DER & Sebelum & 33 & 0,48401 & 0,05 & Normal \\
TATO & Sebelum & 33 & 0,14970 & 0,05 & Normal \\
CR & Sesudah & 33 & 0,12400 & 0,05 & Normal \\
ROA & Sesudah & 33 & 0,26500 & 0,05 & Normal \\
ROE & Sesudah & 33 & 0,12500 & 0,05 & Normal \\
DER & Sesudah & 33 & 0,10000 & 0,05 & Normal \\
TATO & Sesudah & 33 & 0,30600 & 0,05 & Normal \\
\hline
\end{tabular}

Sumber: Data diolah, 2018

Tabel 5

Hasil Uji Normalitas Pada Kinerja Keuangan Perusahaan yang Mengalami Financial Distress Sebelum dan Sesudah Merger dan Akuisisi

\begin{tabular}{cccccc}
\hline \multicolumn{2}{c}{ Variabel } & N & Sig. (2.tailed) & Taraf Sig. & Kesimpulan \\
\hline CR & Sebelum & 10 & 0,99020 & 0,05 & Normal \\
ROA & Sebelum & 10 & 0,94950 & 0,05 & Normal \\
ROE & Sebelum & 10 & 0,35653 & 0,05 & Normal \\
DER & Sebelum & 10 & 0,66398 & 0,05 & Normal \\
TATO & Sebelum & 10 & 0,46236 & 0,05 & Normal \\
CR & Sesudah & 10 & 0,22712 & 0,05 & Normal \\
ROA & Sesudah & 10 & 0,22108 & 0,05 & Normal \\
ROE & Sesudah & 10 & 0,18009 & 0,05 & Normal \\
DER & Sesudah & 10 & 0,14634 & 0,05 & Normal \\
TATO & Sesudah & 10 & 0,30024 & 0,05 & Normal \\
\hline
\end{tabular}

Sumber: Data diolah, 2018

\section{Tabel 6}

Hasil Uji Normalitas Pada Kinerja Keuangan Perusahaan yang Tidak Mengalami Financial Distress Sebelum dan Sesudah Merger dan Akuisisi

\begin{tabular}{cccrcc}
\hline \multicolumn{2}{c}{ Variabel } & N & Sig. (2.tailed) & Taraf Sig. & Kesimpulan \\
\hline CR & Sebelum & 23 & 0,46300 & 0,05 & Normal \\
ROA & Sebelum & 23 & 0,91279 & 0,05 & Normal \\
ROE & Sebelum & 23 & 0,18871 & 0,05 & Normal \\
DER & Sebelum & 23 & 0,93792 & 0,05 & Normal \\
TATO & Sebelum & 23 & 0,44756 & 0,05 & Normal \\
CR & Sesudah & 23 & 0,59233 & 0,05 & Normal \\
ROA & Sesudah & 23 & 0,12053 & 0,05 & Normal \\
ROE & Sesudah & 23 & 0,07189 & 0,05 & Normal \\
DER & Sesudah & 23 & 0,73780 & 0,05 & Normal \\
TATO & Sesudah & 23 & 0,13259 & 0,05 & Normal \\
\hline \multicolumn{5}{l}{ Sumber: Data diolah, 2018 }
\end{tabular}

Berdasarkan hasil uji normalitas diatas, dapat diketahui bahwa semua data kinerja keuangan perusahaan pada seluruh sampel, pada perusahaan yang 
mengalami financial distress dan pada perusahaan yang tidak mengalami financial distress sebelum dan sesudah merger dan akuisisi memiliki nilai probabilitas yang lebih besar dari taraf signifikansi $(\alpha=0,05)$ sehingga dapat disimpulkan bahwa keseluruhan data-data rasio keuangan berdistribusi normal. Oleh karena seluruh data berdistribusi normal, maka alat uji yang digunakan untuk menguji hipotesis penelitian adalah Paired Sample T Test.

Uji paired sample t test akan digunakan untuk menguji hipotesis yang digunakan pada penelitian ini. Apabila tingkat signifikansinya lebih tinggi dari 0,05 maka dapat disimpulkan bahwa terdapat perbedaan kinerja keuangan perusahaan setelah merger dan akuisisi. Namun, apabila tingkat signifikansinya lebih rendah dari 0,05 maka dapat disimpulkan bahwa tidak terdapat perbedaan kinerja keuangan setelah merger dan akuisisi. Hasil uji paired sample t test pada kinerja keuangan perusahaan sebelum dan sesudah merger dan akuisisi selanjutnya disajikan pada tabel 7 sebagai berikut:

Tabel 7.

Hasil Uji Paired Sample T Test pada Kinerja Keuangan Perusahaan Sebelum dan Sesudah Merger dan Akuisisi

\begin{tabular}{lrrrrr}
\hline & $\begin{array}{c}\text { Selisih } \\
\text { Rata-Rata }\end{array}$ & T & $\begin{array}{l}\text { Sig. (2- } \\
\text { tailed) }\end{array}$ & $\boldsymbol{\alpha}$ & Kesimpulan \\
\hline Current Ratio & 0,0818 & 0,3382 & 0,7374 & 0,05 & Tidak berbeda \\
Return on Assets & $-0,0313$ & $-1,9348$ & 0,0619 & 0,05 & Tidak berbeda \\
Return on Equity & $-0,0927$ & $-1,8877$ & 0,0682 & 0,05 & Tidak berbeda \\
Debt to Equity & 0,1333 & 0,6636 & 0,5117 & 0,05 & Tidak berbeda \\
Total Asset Turnover & $-0,2352$ & $-1,6152$ & 0,1161 & 0,05 & Tidak berbeda \\
\hline Sumber: Data diolah, 2018 & & & & &
\end{tabular}

Pada tabel 7 tampak bahwa seluruh rasio keuangan memiliki tingkat signifikansi yang lebih besar dari 0,05. Hasil ini yang menunjukkan bahwa rasio keuangan perusahaan tidak memiliki perbedaan yang signifikan pasca merger dan akuisisi. Berdasarkan hasil tersebut maka dapat disimpulkan bahwa kinerja 
keuangan perusahaan tidak mengalami peningkatan pasca merger dan akuisisi. Hasil uji paired sample t test kinerja keuangan perusahaan pada perusahaan yang mengalami financial distress sebelum dan sesudah merger dan akuisisi selanjutnya akan disajikan pada Tabel 8.

Tabel 8.

Hasil Uji Paired Sample T Test pada Kinerja Keuangan Perusahaan Sebelum dan Sesudah Merger dan Akuisisi pada Perusahaan yang Mengalami Financial Distress

\begin{tabular}{lrrrrr}
\hline & Selisih Rata-Rata & T & Sig. (2-tailed) & $\boldsymbol{\alpha}$ & Kesimpulan \\
& & & & & \\
\hline Current Ratio & 0,1720 & 0,3859 & 0,7085 & 0,05 & Tidak berbeda \\
Return on Asset & 0,0110 & 0,3620 & 0,7257 & 0,05 & Tidak berbeda \\
Return on Equity & $-0,0890$ & $-0,6893$ & 0,5080 & 0,05 & Tidak berbeda \\
Debt to Equity & $-0,2150$ & $-0,3794$ & 0,7132 & 0,05 & Tidak berbeda \\
Total Asset Turnover & 0,1930 & 1,2948 & 0,2276 & 0,05 & Tidak berbeda \\
\hline Sumber: Data diolah, 2018 & & & & &
\end{tabular}

Sumber: Data diolah, 2018

Pada tabel 8 tampak bahwa seluruh rasio keuangan memiliki tingkat signifikansi yang lebih besar dari 0,05. Hasil ini menunjukkan bahwa rasio keuangan perusahaan tidak memiliki perbedaan yang signifikan pasca merger dan akuisisi pada perusahaan yang mengalami financial distress. Berdasarkan hasil tersebut maka dapat disimpulkan bahwa kinerja keuangan perusahaan yang mengalami financial distress tidak mengalami peningkatan pasca merger dan akuisisi. Hasil uji paired sample $t$ test kinerja keuangan perusahaan pada perusahaan yang tidak mengalami financial distress sebelum dan sesudah merger dan akuisisi selanjutnya akan disajikan pada Tabel 9. 
Tabel 9.

Hasil Uji Paired Sample T Test pada Kinerja Keuangan Perusahaan Sebelum dan Sesudah Merger dan Akuisisi pada Perusahaan yang Tidak Mengalami Financial Distress

\begin{tabular}{lccccc}
\hline & Selisih Rata-Rata & T & Sig. (2-tailed) & $\boldsymbol{\alpha}$ & Kesimpulan \\
& & & & & \\
\hline Current Ratio & 0,0426 & 0,1450 & 0,8860 & 0,05 & Tidak berbeda \\
Return on Asset & $-0,0509$ & $-2,7710$ & 0,0110 & 0,05 & Berbeda \\
Return on Equity & $-0,0952$ & $-2,0820$ & 0,0490 & 0,05 & Berbeda \\
Debt to Equity & 0,2848 & 1,8500 & 0,0780 & 0,05 & Tidak berbeda \\
Total Asset Turnover & $-0,4213$ & $-2,2490$ & 0,0350 & 0,05 & Berbeda \\
\hline Sumber: Data diolah, 2018 & & & & &
\end{tabular}

Tabel 9 menunjukkan bahwa hanya rasio CR dan DER yang memiliki nilai signifikansi lebih tinggi dari 0,05 sehingga dapat dikatakan bahwa kedua rasio tersebut tidak mengalami perbedaan signifikan pasca merger dan akuisisi. Rasio lainnya yakni ROA, ROE, dan TATO memiliki nilai signifikansi yang lebih rendah dari 0,05 sehingga dapat dikatakan bahwa ketiga rasio tersebut memiliki perbedaan yang signifikan meskipun perbedaan tersebut mengarah pada penurunan kinerja pasca merger dan akuisisi. Berdasarkan hasil tersebut maka dapat disimpulkan bahwa kinerja keuangan perusahaan yang tidak mengalami financial distress tidak mengalami peningkatan pasca merger dan akuisisi.

Pada penelitian ini, hipotesis pertama yang dirumuskan adalah terdapat peningkatan kinerja keuangan perusahaan setelah merger dan akuisisi. Namun, pengujian menggunakan alat uji paired sample t test menunjukkan hasil yang berbeda yakni kinerja keuangan perusahaan justru mengalami penurunan setelah merger dan akuisisi dilaksanakan. Hal tersebut dapat dilihat dari nilai negatif yang timbul pada selisih rata-rata rasio keuangan sesudah dan sebelum merger dan akuisisi. Pada selisih rata-rata tersebut tampak bahwa hanya rasio CR dan DER 
yang memiliki nilai positif, sedangkan rasio ROA, ROE dan TATO memiliki nilai negatif.

Nilai positif pada rasio $\mathrm{CR}$ menunjukkan perusahaan mengalami peningkatan jumlah aktiva lancar atau penurunan hutang lancar setelah merger dan akuisisi. Aksi korporasi merger dan akuisisi membuat perusahaan memperoleh tambahan aktiva lancar dan aktiva tetap yang dapat dimanfaatkan perusahaan untuk meningkatkan perolehan laba perusahaan. Laba yang diperoleh perusahaan dapat dipergunakan untuk melunasi hutang perusahaan khususnya hutang jangka pendek yang memiliki masa pembayaran yang lebih singkat.

Nilai negatif pada rasio ROA menunjukkan rata-rata perusahaan mengalami penurunan kemampuan untuk memanfaatkan aset yang dimilikinya sehingga laba yang diperoleh perusahaan menurun dan bahkan justru perusahaan mengalami kerugian. Nilai negatif juga timbul pada rasio ROE yang menunjukkan bahwa perusahaan mengalami penurunan kemampuan untuk memanfaatkan ekuitas yang dimilikinya sehingga laba yang diperoleh perusahaan menurun dan bahkan justru perusahaan dapat mengalami kerugian. Perusahaan umumnya menggunakan dana pinjaman dan menerbitkan right issue untuk membiayai aktifitas merger dan akuisisinya. Namun, perusahaan kerap terjebak dalam synergy trap dimana perusahaan membayar terlalu banyak pada perusahaan yang menjadi target merger dan akuisisinya (Cartwright, S. and Schoenberg, R., 2006)

Persaingan yang timbul untuk mengakuisisi atau merger suatu perusahaan khususnya perusahaan yang dinilai memiliki kinerja yang baik membuat perusahaan target mampu meningkatkan nilai jualnya dan perusahaan yang 
menyadari persaingan tersebut akan tergesa-gesa mengakuisisi atau melakukan merger dengan perusahaan tersebut. Biaya merger dan akuisisi yang terlalu besar mengakibatkan sebagian besar laba perusahaan digunakan untuk melunasi hutang dan bunga hutang perusahaan sehingga laba perusahaan menurun dan apabila laba perusahaan terlalu rendah, perusahaan justru akan mengalami kerugian akibat pelunasan hutang tersebut.

Nilai positif pada rasio DER menunjukkan rata-rata peningkatan jumlah hutang yang dimiliki perusahaan dibandingkan dengan ekuitas yang dimilikinya. Peningkatan hutang ini disebabkan karena umumnya perusahaan menggunakan dana pinjaman untuk membiayai merger dan akuisisinya. Nilai negatif pada rasio TATO menunjukkan bahwa rata-rata perusahaan mengalami penurunan efisiensi dalam pemanfaatan aktiva yang dimilikinya sehingga nilai penjualan perusahaan tidak mengalami peningkatan atau justru mengalami penurunan setelah merger dan akuisisi dilaksanakan.

Hasil penelitian ini sejalan dengan penelitian dari Usadha (2009), Haryetti (2010), Alger (2015), dan Annisa (2017) yang menyatakan bahwa penurunan kinerja keuangan pasca merger dan akuisisi disebabkan karena belum tercapainya sinergi antar kedua perusahaan pasca merger dan akusisi yang relatif singkat. Thomas Belz et al., (2013) dalam penelitiannya menemukan bahwa kemampuan perusahaan dalam menghasilkan laba tidak mengalami peningkatan pasca merger dan akuisisi yang disebabkan karena manajemen memiliki motif tertentu yang melandasi merger dan akuisisi. Salah satunya yaitu tax avoidance. Secara definisi, tax avoidance merupakan suatu metode pengurangan pajak suatu perseorangan 
atau badan usaha dengan memanfaatkan celah-celah peraturan perpajakan yang dapat dilakukan secara legal tanpa melanggar hukum (Roberson, 2015).

Perusahaan yang memiliki pengalaman manajemen pajak yang lebih baik akan mampu melakukan efisiensi terhadap beban pajak yang dimiliki perusahaan target. Beban pajak yang lebih rendah pada perusahaan target membuat perusahaan mampu meningkatkan arus kas yang diperoleh dari perusahaan target pasca merger dan akuisisi. Meksipun demikian, dalam penelitiannya Thomas Belz et al.,(2013) tidak menemukan adanya peningkatan profitabilitas perusahaan pasca merger dan akuisisi.

Pada penelitian ini, hipotesis kedua yang dirumuskan adalah terdapat peningkatan kinerja keuangan perusahaan setelah merger dan akuisisi pada perusahaan yang mengalami financial distress. Berdasarkan hasil uji paired sample $t$ test, kinerja keuangan perusahaan pada perusahaan yang mengalami financial distress tidak mengalami perbedaan yang signifikan pasca merger dan akuisisi. Hasil uji paired sample $t$ test juga menunjukkan bahwa kelima rasio keuangan yang digunakan tidak mengalami perbedaan yang signifikan pasca merger dan akuisisi maka dapat disimpulkan bahwa kinerja keuangan perusahaan pasca merger dan akuisisi tidak mengalami peningkatan.

Perusahaan akan menerima tambahan aset setelah merger dan akuisisi dilakukan sedangkan hutang jangka pendek perusahaan umumnya tidak menunjukkan adanya perbedaan. Nilai rasio CR positif ini juga tidak lepas dari kecenderungan perusahaan untuk menggunakan hutang jangka panjang dalam membiayai kebutuhan operasionalnya. 
Perusahaan yang mengalami financial distress memiliki pertumbuhan laba yang lebih rendah dibandingkan dengan perusahaan yang sehat. Perusahaan perlu mengkaji faktor-faktor yang menjadi penyebab rendahnya tingkat pertumbuhan ini, mulai dari tingkat efektifitas, efisiensi, pangsa pasar dan juga keberadaan pesaing (Frans Julius, 2017). Salah satu dari keempat masalah tersebut dapat terselesaikan dengan waktu relatif singkat melalui merger dan akuisisi. Merger dan akuisisi memberikan tambahan pangsa pasar kepada pihak pengakuisisi apabila merger dan akuisisi tersebut melibatkan perusahaan pada sektor bisnis yang sama.

Pangsa pasar yang lebih besar terbukti mampu dimanfaatkan perusahaan untuk meningkatkan pertumbuhan penjualan dan labanya meskipun tidak signifikan. Hal ini terlihat pada selisih rata-rata ROA dan TATO yang mengalami peningkatan pasca merger dan akuisisi meskipun tidak signifikan. Tambahan aset yang diterima pasca merger dan akuisisi, mampu digunakan secara efektif dan efisien. Berbeda dengan perusahaan yang sehat, manajemen pada perusahaan yang mengalami financial distress dihadapkan pada tekanan yang lebih besar.

Pasca merger dan akuisisi perusahaan juga memperoleh tambahan ekuitas, yang apabila mampu dimanfaatkan oleh manajemen tentu perusahaan akan mengalami peningkatan kinerja yang lebih baik. Namun, nilai ROE yang menurun menunjukkan bahwa perusahaan belum mampu memanfaatkan tambahan ekuitas yang diperoleh pasca merger dan akuisisi. Penjualan dan laba yang bertambah namun diikuti dengan pertambahan ekuitas yang lebih besar menyebabkan nilai ROE tampak mengalami penurunan. 
Hasil penelitian ini memperkuat penelitian dari Jean Marie (2014), Anna Faelten dan Valeriya Vitkova (2014), Stuart Gilson (2015), Mohammed Shariq (2016) dan Wolvers (2017) yang dalam penelitiannya menyebutkan bahwa kunci keberhasilan perusahaan dalam memperbaiki kinerja keuangannya terletak pada efektifitas dan efisiensinya. Manajemen pada perusahaan yang mengalami tren penurunan kinerja umumnya memiliki tekanan yang lebih besar dari para pemegang saham, dan lebih beresiko kehilangan investor dibandingkan perusahaan yang sehat. Hal inilah yang membuat manajemen bergerak dengan terencana dan berhati-hati terlebih dalam melakukan strategi merger dan akuisisi sehingga secara umum perusahaan yang mengalami financial distress akan berada pada langkah yang tepat untuk memperbaiki kinerjanya (Tih Kon Tan, 2012).

Perusahaan yang tidak mengalami financial distressmemiliki kemampuan yang labih baik dalam hal efektifitas dan efisiensi operasionalnya. Meskipun demikian, tampaknya sulit untuk melihat peningkatan kinerja keuangan pasca merger dan akuisisi dalam jangka pendek pada perusahaan yang tidak mengalami financial distress. Hal ini terlihat pada selisih rata-rata rasio keuangan yang digunakan untuk mengukur seberapa baik kinerja keuangan pasca merger dan akuisisi. Lima rasio keuangan digunakan untuk mengukur kinerja keuangan tersebut dan dari kelima rasio yang digunakan terdapat rasio CR dan DER yang memiliki hasil selisih rata-rata positif serta rasio ROA, ROE dan TATO yang bernilai negatif.

Perusahaan mengalami peningkatan rasio CR dan DER yang berarti aktiva dan keseluruhan hutang perusahaan mengalami peningkatan pasca merger dan 
akuisisi. Namun, tingkat efektifitas dan efisiensi perusahaan justru mengalami penurunan yang dapat dilihat dari nilai negatif pada rasio ROA, ROE, dan TATO yang cukup signifikan. Berdasarkan hasil tersebut dapat disimpulkan bahwa kinerja keuangan pada perusahaan yang tidak mengalami financial distress mengalami memiliki perbedaan yang signifikan meskipun perbedaan tersebut mengarah kepada penurunan pasca merger dan akuisisi yang sekaligus menolak hipotesis ketiga dalam penelitian ini.

Jika dilihat dari sisi keuangan, perusahaan yang tidak mengalami financial distress tentu memiliki keuangan yang lebih baik. Namun, terdapat berbagai faktor yang dapat menghambat peningkatan kinerja keuangan pasca merger dan akuisisi terlepas dari kondisi keuangan yang dialami oleh perusahaan. Faktorfaktor tersebut berupa kurangnya perencanaan yang matang, timetable yang terlalu singkat dalam menyelesaikan kesepakatan merger, kurangnya memperhatikan masalah yang timbul setelah integrasi merger, dan peramalan strategi yang berubah menjadi ilusi (Sherman, 2010).

Tingkat kegagalan yang tinggi dari merger dan akusisi juga disebabkan oleh kurangnya pertimbangan terhadap perbedaan yang dimiliki oleh kedua perusahaan sebelum merger dan setelah merger. Kegagalan yang timbul pada tahap awal merger dapat di telusuri ke dalam synergy trap seperti ketika sebuah organisasi membayar terlalu banyak pada perusahaan target karena motif manajerial (Wachtell et al., 2017).

Masalah yang mungkin muncul pada tahap setelah merger dan akusisi berupa masalah integrasi yang juga harus dipertimbangkan dalam menganalisa 
kegagalan sinergi pasca merger dan akuisisi (Taofik Bouraoui and Ting Lim, 2014). Bukan hanya kesesuaian strategi dalam merger dan akuisisi yang harus diraih, namun kesesuaian organisasional, yang berarti adanya kemiripan budaya, sistem dan struktur yang akan akan menunjang peningkatan kinerja pasca merger dan akuisisi (Waight, 2004). Berbagai faktor tersebut berkontribusi pada kemampuan perusahaan dalam memanfaatkan tambahan aktiva, kewajiban dan hutang pasca merger dan akuisisi.

Berbeda dengan perusahaan yang mengalami financial distress, perusahaan yang memiliki kondisi keuangan yang baik hanya perlu menganalisa, memanfaatkan potensi perusahaan yang diakuisisi serta menyesuaikannya dengan strategi yang dimiliki perusahaan. Penurunan selisih rata-rata ROA, ROE dan TATO pasca merger dan akuisisi menunjukkan perusahaan masih berfokus dalamBouraoui, Taofik and Ting Li. 2014. Restrukturisasi dan penyelesaian administrasi perusahaan selama satu hingga dua tahun pasca merger dan akuisisi (Frederick, 2012). Penurunan laba yang diterima perusahaan pasca merger dan akuisisi juga disebabkan karena bertambahnya persentase biaya yang harus dialokasikan untuk pemenuhan hutang perusahaan sehingga alokasi laba untuk pos-pos operasional lainnya berkurang dan berdampak pada penurunan penjualan.

Hasil penelitian ini memperkuat penelitian dari Verawati dan Supardi (2005), Frederick (2012), Hendra (2013), Jean Meier (2013)Prisya Esterlina (2017) dan Arisnanti (2017). Pada penelitian mereka dapat disimpulkan bahwa faktor perencanaan dan kesesuaian strategi menjadi faktor yang paling dominan dalam menghambat peningkatan kinerja keuangan perusahaan pasca merger dan 
akuisisi. Kinerja keuangan perusahaan yang tidak mengalami peningkatan seakan mengindikasikan perusahaan memiliki motif lain dalam melakukan merger dan akuisisi seperti tax inversion.

\section{SIMPULAN}

Kinerja keuangan pada keseluruhan perusahaan mengalami penurunan setelah merger dan akuisisi yang terlihat pada penurunan rasio ROA, ROE dan TATO pasca merger dan akuisisi. Penemuan ini sekaligus menolak hipotesis pertama yang digunakan pada penelitian ini. Rasio CR dan DER mengalami peningkatan akibat penambahan aktiva, modal dan hutang pasca merger dan akuisisi. Penurunan kinerja ini juga mengisyaratkan bahwa perusahaan belum dapat mencapai sinergi dalam jangka pendek yakni pada dua tahun pasca merger dan akuisisi.

Kinerja keuangan pada perusahaan yang mengalami financial distress tidak mengalami peningkatan pasca merger dan akuisisi. Hal ini terlihat pada adanya perubahan rasio $\mathrm{CR}$, ROA, TATO, DER dan ROE yang sama-sama tidak signifikan. Peningkatan penjualan dan laba perusahaan yang tidak lebih tinggi dari penambahan ekuitas perusahaan menunjukkan bahwa perusahaan belum mampu memaksimalkan potensi tambahan modal yang diperoleh pasca merger dan akuisisi dalam jangka pendek.

Kinerja keuangan pada perusahaan yang tidak mengalami financial distress mengalami penurunan pasca merger dan akuisisi. Penurunan kinerja keuangan pada perusahaan yang tidak mengalami financial distress sekaligus menolak hipotesis ketiga yang digunakan pada penelitian ini. Penurunan kinerja 
keuangan perusahaan ini dapat disebabkan karena perencanaan manajemen yang kurang matang, kesesuaian strategi yang rendah dan juga kesesuaian organisasional yang rendah antar kedua perusahaan ataupun manajemen memiliki motif lain dalam melakukan merger dan akuisisi seperti tax inversion.

Manajemen dan investor perlu menganalisa terlebih dahulu kondisi keuangan perusahaan yang dijadikan target merger dan akuisisi. Manajemen dan investor dapat menggunakan model prediksi kebangkrutan milik Altman yang disebut dengan Altman Z-Score yang hingga saat ini masih relevan untuk digunakan. Analisa ini diperlukan agar manajemen dan investor memiliki perencanaan yang matang terkait dengan strategi yang akan digunakan dalam merger dan akuisisi. Selain kondisi keuangan, perusahaan juga harus menganalisa kesesuaian organisasi, budaya, dan juga faktor-faktor lain yang dinilai dapat mempengaruhi pencapaian sinergi pasca merger dan akuisisi.

Periode pengamatan yang digunakan dalam penelitian ini relatif singkat yakni hanya dua tahun pasca merger dan akuisisi sehingga sulit untuk melihat pencapaian sinergi perusahaan dalam jangka pendek. Peneliti selanjutnya perlu memperpanjang waktu pengamatan khususnya pasca merger dan akuisisi untuk melihat pencapaian sinergi perusahaan dalam jangka panjang.

\section{REFERENSI}

Altman, E. 1968. Financial Ratios, Discriminant Analysis and the Prediction of Corporate Bankruptcy. Journal of Finance 23, September 1968, Hal : 589609.

Begley J., Ming J. and Watts S. 1996. Bankruptcy Classification Errors in the 1980s: An Empirical Analysis of Altman's and Ohlson's Models. Review of Accounting Studies, 1(4), Hal :267-284. 
Bouraoui, Taofik and Ting Li. 2014.The Impact of Adjustment in Capital Structure in Mergers \& Acquitions on US Acquierers' Business Performance.The Journal of Applied Business Research, 30 (1), February 2014.

Bruyland, Evy. 2011. The Risk Effect of Acquiring Distressed Firms. Vlerick Leuven Gent Working Paper Series 2011 (14). Autonomous Management Scholl of Ghent University and Katholieke Universiteit Leuven.

Cartwright, S. and Schoenberg, R. 2006. Thirty Years of Mergers and Acquisitions Research: Recent Advances and Future Opportunities.British Journal of Management, 17 (1).

Camara, D. and Renjen P. 2004. The Secrets of Successful Mergers: Dispatches from the Front Lines. The Journal of Business Strategy, 25 (3), Hal : 10-14

Darlis, Edfan dan Zirman. 2009. Dampak Publikasi Akuisisi pada Perusahaan Pengakuisisi. Jurusan Akuntansi Fakultas Ekonomi Universitas Riau, Pekan Baru.

Esterlina, Prisya. 2017. Analisis Kinerja Keuangan Perusahaan Sebelum dan Sesudah Merger dan Akuisisi. Jurnal Administrasi Bisnis, 47 (2), Juni 2017. Fakultas Ilmu Administrasi Universitas Brawijaya, Malang.

Faelten, Anna dan Valeriya Vitkova. 2014. Who Gains from Corporate Rescues ? Distressed M\&A during For Financial Crisis. Mergers and Acquisitions Research Centre. Cass Business Scholl, City University, London.

Fahlevi, Ali Riza. 2013. Faktor-Faktor yang Mempengaruhi Merger dan Akuisisi. Universitas Diponogoro.

Gilson, Stuart, Edith Hotchkiss and Matthew Osborn. 2015. Cashing out : The Rise of M\&A in Bankruptcy. Working Paper, 15 (67), January 2015.

Haryetti. 2010. Analisis Financial Distress untuk Memprediksi Risiko Kebangkrutan Perusahaan. Jurnal Ekonomi, 18 (2). Fakultas Ekonomi UNRI, Pekanbaru.

Heyer, Ken dan Sheldon Kimmel. 2009. Merger Review of Firms in Financial Distress. EAG, 9 (1).

Julius, Frans P.S. 2017. Pengaruh Financial Leverage, Firm Growth, Laba dan Arus Kas Terhadap Financial Distress. JOM, 4 (1). Fakultas Ekonomi Universitas Riau, Pekanbaru. 
Meier, Jean-Marie dan Henri Servaes. 2013. Distressed Acquisitions. London Bussiness Journal.

Mas'ud, Imam dan Reva Maymi Srengga. 2012. Analisis Rasio Keuangan untuk Memprediksi Kondisi Financial Distress Perusahaan Manufaktur yang Terdaftar di Bursa Efek Indonesia. Fakultas Ekonomi Universitas Jember, Jember, Jawa Timur.

Mohammed, Shariq. 2016. Bankruptcy Prediction by Using the Altman Z-score Model in Oman: A Case Study of Rasyut Cement Company SAOG and its Subsidiaries. Australasian Accounting, Businessvand Finance Journal, 10(4), Hal : 71-80. University of Wolonggong Australia.

Novaliza, Putri. 2013. Analisis Pengaruh Merger dan Akuisisi Terhadap Kinerja Perusahaan Publik di Indonesia (Periode 2004-2011). Jurnal Akuntansi dan Bisnis, Perbanas Institute. 1 (2), September 2013.

Platt, H., dan M. B. Platt. 2002. Predicting Financial Distres. Journal of Financial Service Professionals, 56: 12-15.

Precourt, Elena. 2016. Acquisitions of Bankrupt and Distressed Firms. International Journal Bonds and Derivatives. 2 (1), Bryan University.

Refnes, Fredrik Oren. 2012. What Explains Mergers Success or Failure ?. Thesis The European Inter-University University of Oslo, Norwegia.

Roberson, C. 2015. Tax evasion. Salem Press Encyclopedia

Sherman, A. 2010. Mergers and Acquisitions from A to Z. Third Edition. New York. American Management Association.

Sugiyono. 2017. Metode Penelitian Kuantitatif, Kualitatif, dan R\&D. Bandung:Alfabeta.

Syaichu, Muhamad. 2006. Merger dan Akuisisi : Alternatif Meningkatkan Kesejahteraan Pemegang Saham. Jurnal Studi Manajemen \& Organisasi. Vol. 3, Nomor 2, Juli 2006-59.

Tan, Tih Koon. 2012. Financial Distress and Firm Performance : Evidence From Asian Financial Crisis. Journal of Finance and Accountancy. The University of Tampa, Florida.

Belz, Thomas, Leasley Robinsin, Martin Ruf and Christian Steven. 2013. Tax Avoidance as Driver of Merger and Acquition. JEL. 
Undang-Undang Republik Indonesia Nomor 40 Tahun 2007 Perseroan Terbatas. 16 Agustus 2007. Lembaran Negara Republik Indonesia Tahun 2007 Nomor 106. Jakarta.

Utami, Annisa Aristanti. 2017. Pengaruh Merger Terhadap Kinerja Keuangan Perusahaan yang Terdaftar di Bursa Efek Syariah. Skripsi Sarjana Jurusan Ekonomi Islam pada Fakultas Ekonomi dan Bisnis Islam Institut Agama Islam Negeri Raden Intan, Lampung.

Wachtell, Lipton et al. 2017. Distressed Mergers and Acquisitions.

Waight, C. L., (2004): HR Involvement in the Investigative Phase of a Merger \& Acquisition. International Journal of Training and Development, 8 (2), Hal : 157-169.

Wolvers, Tsette. 2017. Short-term Effect of Acquiring a Financially Distressed Firm. Thesis. Erasmus Universiteit Rotterdam.

Yulia, Anggi. Analisis Kebangkrutan Metode Altman Z-Score pada Perusahaan Rokok Go Public. Jurnal Ilmu dan Riset Manajemen. Sekolah Tinggi Ilmu Ekonomi Indonesia Surabaya. Vol.II, No.2, 2013.

Zang, Quxian. 2016. Why Do Distressed Firms Acquired. Job Markert Paper. Erasmus University. 